\title{
Reflections
}

\section{Borrowed feathers or Jugad}

am quite fresh from having spoken at a meeting convened for celebrating 5000 free flaps for reconstructing defects following the excision of malignant tumours at a hospital in this city (Mumbai). The recent issue of the Indian Journal of Plastic Surgery also gives a glimpse of the expertise that surgeons in India have acquired in the field of microsurgery and homologous composite tissue transfer. There are other centres in this country where people from abroad come to learn not only the techniques of microsurgery but also how to organise and run plastic surgery units. There are young surgeons in district places and small towns who now offer microsurgical expertise at a fraction of the cost that microsurgery entails in corporate hospitals in big cities. I imagine that almost all post-graduates who emerge from our teaching hospitals are now familiar with microsurgical techniques, and a senior resident in most large teaching hospitals can undertake a replant with confidence. It is obvious that things will only improve over the years in spite of losses of our trainees to non-reconstructive purely aesthetic pursuits. Microsurgery is now a basic requirement in all fields of surgery. In some late news just received by a member of this society, the Indian Society for Reconstructive Microsurgery has just been included under the prestigious Sunderland club, which has its focus on the treatment of peripheral nerves.

India missed the industrial/scientific revolution and also simultaneously got colonised. In a way the latter was a result of the former. A people or a nation gets colonised when their internal social systems fail creating a vacuum in which the coloniser arrives. When the technological revolution came, we were better off. We were independent and had a sizable population of educated engineers and luckily economic liberalisation followed soon after. That circumstance spawned the software industry in which we excelled. We were good at copying what was already discovered and also modifying it. This in colloquial language is called Jugad. We also supplied intelligent professionals to the software industry abroad. In a way, the flow had reversed and the western democracies are now feeling threatened by this export of soft power. However, here too Indians were in the zone of 'innovation and execution', and our achievements were not in the realm of fundamental ideas, for example, artificial intelligence and even if we become a part of that project that participation will remain offshore. Space technology and delivery of multiple satellites at one go from our space stations here in India is an exception to this rule. An analysis of this success might show us a path forwards in other areas of science as well as in our speciality.

In front of this backdrop, it is interesting to read the history of transfer of tissues in plastic surgery. If the first 30 years of the $20^{\text {th }}$ century belonged to physics, the past 30 years belonged to the exponential growth in managing tissue transfers. Replantation is also a subset of tissue transfer. It was Milton's work on the length-breadth ratio in flaps on the back of pigs that highlighted the importance of the axial vessel in the base of the flap. It did two things (1) it set the cat amongst the traditionalist pigeons and (2) it explained the mystery of the success of some flaps which were succeeding in spite of outrageous length breadth ratios. Please realise Milton was only a general surgeon. The groin flap was only a natural extension of what Milton had shown and was the first axial pattern flap to be transferred as a free microvascular flap. That opened the floodgates. The muscle flap was recognised as a very natural axial pattern flap, and the deep fascia claimed its rightful place in this form of surgery because the fascia was the curtain through and around which the blood vessels ultimately traversed to reach the skin and the subcutaneous tissue. That also brought the word 'the perforator' into our scientific lexicon, and these perforators have been put to great use in a variety of transfers of tissue. India's contribution to this progress was negligible or almost nothing though three if not more Asian countries contributed handsomely to this progress. I name three, China together with Taiwan, Japan and South Korea. Those three countries in those 30 years and later created wealth despite the fact that their political systems were quite different from each other. They invested in scientific research and also created a scientific ethos which allowed opportunities to aspiring scientist $\backslash$ professionals. Please realise that the English language was alien to them yet they succeeded. 
We, on the other hand, are far better connected to the scientific world because we are well versed in English but have lagged behind.

The creation of wealth began in India in the middle of the nineties of the past century, and judging by recent events it appears that the world is now accepting us at the high table in many an international monetary and financial meetings. The question is will this wealth now result in scientific advances and a certain productive scientific temper and atmosphere.

As I foresee the future, improved optics, three-dimensional preoperative imaging in planning surgical procedures, less destructive lasers, guided invasive automation for the treatment of lesions in hollow organs, artificial intelligence and robotic techniques are already at our doorsteps. Some of us might disbelieve this but within 5 years a cleft of the palate may be operated with the help of robotic appliance. Please realise that the mouth is far bigger than the hole that is made for a robotic laparoscopic prostatectomy. Microsurgery with rings to anastomose vessels applied by a robot should not be far away. Industry will tempt us and get away with it. All this already is or will become a fait accompli. Industry may or may not be interested in patients, but they are forever looking for products and profits.

One scenario of interest to us that lurks in the future is availability of 'off the shelf tissues'. In the present, this is restricted to small parts which are either preserved or 'tissue engineered', for example, valves or ligaments. On the other hand, if organs are being harvested for transplants and if they survive including homologous composite transfers, can flaps too be so harvested from brain-dead patients? After all cadaveric bone grafts are now being used quite frequently and we all know that the bone is a complex tissue. It would be prudent not to reject the idea of homologous cadaveric flaps outright but to keep it at the back of our minds. It will need a lot of doing but just imagine a single brain-dead patient can offer us at least six flaps which can be harvested at the level of large-sized truncal vessels and can be subjected to a variety of experiments. The size of the harvest should be such as to enable us to close the defect and eliminate mutilation. These flaps can be loaded with anticoagulants, they can be frozen, they can be lyophilised, or they can be hooked on to an extracorporeal circulation machine and examined at intervals to find what happens to them and how we can render them into a piece of tissue which is immunologically degraded enough to be offered as a cover by a simple anastomosis of the truncal vessels and what is more they can be flow through flaps. What we should aim for is a vascular piece of tissue which will cover a defect and reduce its life or limb-threatening potential. I believe that some giants in the field of microsurgery here in India are now accepting of a split-skin homograft temporarily to reduce the gravity of the effects of trauma. As a further step, why not a homo flap?

I do not speak off the cuff and in the air nor am I an armchair philosopher because nearly twenty-five years ago, we tried to keep a flap in the dog alive with the help of extracorporeal circulation. The attempt failed. Our intention behind the effort was to avoid the onslaught of microsurgery in our impoverished unit with a huge workload in a general hospital. The work though had interesting consequences and a large unipedicled venous fasciocutaneous flap came to be described, and further work showed some extraordinary features of venous circulation. The world moved on and was soon inundated with microsurgery. I was called a lateral thinker at best and a crank at the worst. However, this is a familiar story in the annals of medicine. I cannot change my nature.

What I am leading to is the fact that the whole of India does not probably have a world-class experimental laboratory for experimenting on tissues. Is this because we are poor? To answer that question, we only need to look at the finances of some of our associations. They have more wealth than they can manage. Even assuming the funds are limited is it true that the associations are unable to raise funds in the future? That too is not true. Some of the allied associations have memberships going into a thousand, and there seems to be a line of members who want to include eponymous lectures of their teachers for which money is offered. I am told these are called podium presentations. When I heard that such a move was on to name a lecture after me, I was appalled. It is about time that we limit future visiting professorships, orations, pomp, and the enormous expenditure on food and beverages and create a corpus for an experimental centre where our members from all disciplines can come to experiment. A brief visit abroad might widen the horizon of the visiting professor, but he or she returns to the same old situation where he or she cannot really do more than copy what was observed somewhere else.

At a rough estimate what is needed is 25 crores. Five crores for land and five crores for the building if it is 
not available readymade in some institution and the remaining 15 crores as a corpus to begin with. Because I compile the short notes in plastic surgery, the blog, commissioned by the association of plastic surgeons of India, I am well acquainted with a large number of extremely talented young surgeons both in plastic and other allied specialities in India whose ingenuity has amazed me. However, this ingenuity or Jugad needs to be upgraded and harnessed towards basic research. They are in dire need of such a facility not for making discoveries which will come in time, discoveries always arrive unexpectedly but first to inculcate in them the true scientific temper and to channelise their energies. This centre can also be a recipient centre for better quality soft cadavers. I notice that some of the cadavers used for workshops are too desiccated for any meaningful learning experience. Moreover, finally, I dare to think that financially this centre, in course of time will become self-supporting, and let me also note here that I have had some experience in raising money worth lakhs for social causes long ago when philanthropy was not in fashion, the word "corporate social responsibility' was yet to be coined and India was said to be economically in the dumps. India in fact has never been a poor country. She has been a disorganised society leading in turn to dishonesty. She, India, is at an inflection point in her history and so are our associations. If the opinion makers in our associations and I can easily count ten in my mind off hand, take it in their mind, this seemingly unattainable goal can be achieved with the greatest of ease, and the foundations of a truly scientific environment can be thus be laid. From then, the sky alone will be the limit. How long can we wear borrowed feathers? It is about time that we grew our own. Any such exhortation in the present is considered as ultra-nationalistic. I have no such qualms as I speak. 'Make in India' is a good idea. As a nation of continental proportions with enormous talent, we owe this to the world at large. Remember, we are the land of Sushruta and the future beckons us.

(Opening remarks at the meeting of the Indian Society for Reconstructive Microsurgery, Mumbai, March 2018).

\section{Ravin Thatte}

\section{Financial support and sponsorship}

Nil.

\section{Conflicts of interest}

There are no conflicts of interest.

\section{Ravin Thatte}

Plastic and Reconstructive Surgeon, Mumbai, Maharashtra, India

Address for correspondence: Prof. Ravin Thatte,

46 Shirish Co-op. Hsg. Society,

187, Veer Savarkar Marg, Mahim, Mumbai - 400016 Maharashtra, India.

E-mail: rlthatte@gmail.com

This is an open access journal, and articles are distributed under the terms of the Creative Commons Attribution-NonCommercial-ShareAlike 4.0 License, which allows others to remix, tweak, and build upon the work non-commercially, as long as appropriate credit is given and the new creations are licensed under the identical terms.

\begin{tabular}{|l|l|}
\hline \multicolumn{2}{|c|}{ Access this article online } \\
\hline Quick Response Code: & Website: \\
\hline
\end{tabular}

How to cite this article: Thatte R. Borrowed feathers or Jugad. Indian J Plast Surg 2018;51:235-7. 